\title{
Vitamin C biochemistry: From scurvy to COVID-19 treatment
}

\author{
${ }^{1}$ Tamara Zakić, ${ }^{1}$ Marta Budnar, ${ }^{1}$ Andjelika \\ Kalezić, ${ }^{2}$ Aleksandra Korać, ${ }^{1}$ Aleksandra \\ Janković, 1,2Bato Korać \\ ${ }^{1}$ Department of Physiology, Institute for \\ Biological Research "Sinisa Stankovic" National \\ Institute of Republic of Serbia; University of \\ Belgrade, Bulevar despota Stefana 142, Belgrade, \\ 11060, Serbia; \\ ${ }^{2}$ Center for Electron Microscopy, Faculty of \\ Biology, University of Belgrade, Studentski trg 16, \\ Belgrade, 11000, Serbia. \\ Corresponding author: \\ Prof Bato Korać \\ Department of Physiology, Institute for Biological \\ Research "Siniša Stanković", National Institute \\ of Republic of Serbia, University of Belgrade, \\ Bulevar despota Stefana 142, Belgrade, 11060, \\ Serbia \\ Phone/fax: (381-11)-2078-307, (381-11)-2761-433 \\ E-mail address: koracb@ibiss.bg.ac.rs \\ Received 21 October 2020 \\ Accepted 05 December 2020
}

\begin{abstract}
The story of vitamin C (L-ascorbic acid) as an antioxidant and a cofactor in numerous biochemical reactions is a part of its long history and it is well known today. However, many questions of its mechanism of action and the benefits that it has on human health are still emerging. This applies not only to the recommended doses but also to the route of its administration. Besides, there are numerous questions about the therapeutic efficacy of vitamin $C$ in various human (infectious) diseases, as well as its immune system function and antiviral potential. The fact that vitamin C can act as a reductant (antioxidant) and a prooxidant further emphasizes its oxidation-reduction (redox) potential in real physiological conditions. Today, the question of the intravenous administration of vitamin C effect in patients with SARS-CoV-2 requires special attention. This review aims to showcase known facts about vitamin $C$ and its mechanisms of action to better understand the current new challenges related to vitamin $C$.
\end{abstract}

Key words: Vitamin C; Metabolism; Antioxidant; Mechanism of action; Physiological function; Immune function; Cancer; Common cold; SARS-COV-2; COVID-19.

\section{HISTORY OF VITAMIN C}

Although its importance in human biology has been known ever since the emersion of scurvy, it was not until the 20th century that vitamin $C$ was discovered. Scurvy is a disease caused by severe vitamin $C$ deficiency, which was very common among sailors on long sea journeys during the early modern period [1-3]. In 1753 Scottish naval surgeon James Lind identified citrus fruits as an effective cure for scurvy in the first-ever controlled clinical study $[1,3,4]$. Still, the reason why the citrus fruits had a therapeutic effect was yet to be discovered. The reducing agent responsible for preventing and curing the disease was first found in 1928 by Hungarian scientist Albert Szent-Györgyi. The offwhite crystalline substance that he isolated from plant juices and animal tissues (adrenal glands) and that he named hexuronic acid was thought to be a new hormone similar to simple sugars [5]. Still, a few years later, Svirbely and Szent-Györgyi confirmed that hexuronic acid was, in fact, vitamin C [6]. At the same time, W. A. Waugh and C. G. King isolated a crystalline vitamin C from lemon juice and reported that it had similar physical and chemical properties as hexuronic acid, including the antiscorbutic quality, and that it was identical with the hexuronic acid, which was indeed later confirmed [7]. In 1933 a team led by British chemist Walter $\mathrm{N}$. Haworth defined the molecular structure of vitamin $C$ (i.e., hexuronic acid), renaming it to the ascorbic acid [8]. Albert Szent-Györgyi and Walter N. Haworth were awarded the Nobel Prize in Physiology or Medicine and Chemistry, respectively, for their work on vitamin C.

\section{VITAMIN C BIOCHEMISTRY}

Vitamin C, also known as L-ascorbic acid, is a white, water-soluble crystalline powder. Ascorbate coexists in two main forms - reduced (L-ascorbic acid or vitamin C) and oxidized (Dehydroascorbic acid, DHA) (Figure 1). The biological functions of ascorbate depend on 
its ability to donate electrons. Ascorbate can serve as a biologically relevant reducing agent in both plasma and tissues. As a result of one-electron oxidation of ascorbate, ascorbyl radical (i.e., monodehydroascorbate) is formed. Ascorbyl radical is an unusually stable, but not very reactive molecule, making it a biologically relevant electron donor. However, dismutation of two molecules of the ascorbyl radical is preferable, forming ascorbate and DHA [9-11]. DHA is then imported into cells, where it can be quickly restored back to ascorbate by $\mathrm{NADH}$-dependent, NADPH-dependent, or glutathione-dependent systems [11-14]. Otherwise, DHA is irreversibly hydrolyzed since it is a relatively unstable molecule at physiological $\mathrm{pH}$, thus the need for efficient DHA reduction to ascorbate in the cells [15].

Ascorbate is synthesized de novo from D-glucose through a cascade of enzyme-catalyzed reactions. The key step which drives the biosynthetic pathway towards ascorbate synthesis is the conversion of UDP-glucuronate to D-glucuronate. Otherwise, UDP-glucuronate can be used for the biosynthesis of specific polysaccharides $[11,14]$. Unlike plants and most other vertebrates, humans do not synthesize ascorbate due to the accumulation of mutations in the Gulo gene, which encodes for the last enzyme in the pathway, L-gulono- $\gamma$-lactone oxidase $[14,16]$. Since vitamin $C$ is an essential micronutrient for humans, it needs to be supplied through dietary sources and supplements [17].

\section{VITAMIN C METABOLISM}

Vitamin $\mathrm{C}$ metabolism is regulated by respective mechanisms - intestinal absorption, transport to tissue, renal reuptake, and urine excretion [18]. After the intake through food or supplementation, vitamin $C$ is then ingested along the gastrointestinal tract (GIT) via specific transporters in both reduced and oxidized forms [19-21]. Ascorbate is directly absorbed by active transport via the sodium-dependent vitamin $C$ transporter 1 (SVCT1). SVCT1 is also expressed in the proximal kidney tubule, where it is involved in the reabsorption of vitamin C. Furthermore, vitamin C can either carry out its function in the blood and extracellular fluid or it can be imported into the cells via SVCT2, a transporter present in nearly every cell type. Plasma vitamin $C$ is filtered by renal glomeruli, but most of it is reabsorbed in the proximal tubule via SVCT1 [21-23]. On the other hand, DHA is absorbed in GIT and imported into cells by facilitated diffusion via GLUT transporters [24,25]. Glucose is considered to be a competitive inhibitor of DHA because it is also transported via GLUTs, which can cause vitamin $C$ deficiency in obese and diabetic individuals $[21,26]$.

Numerous endogenous and exogenous factors have an impact on vitamin $C$ bioavailability in the body. The recommended dietary allowance (RDA) for vitamin $C$ varies from $45 \mathrm{mg} /$ day (World Health Organization)

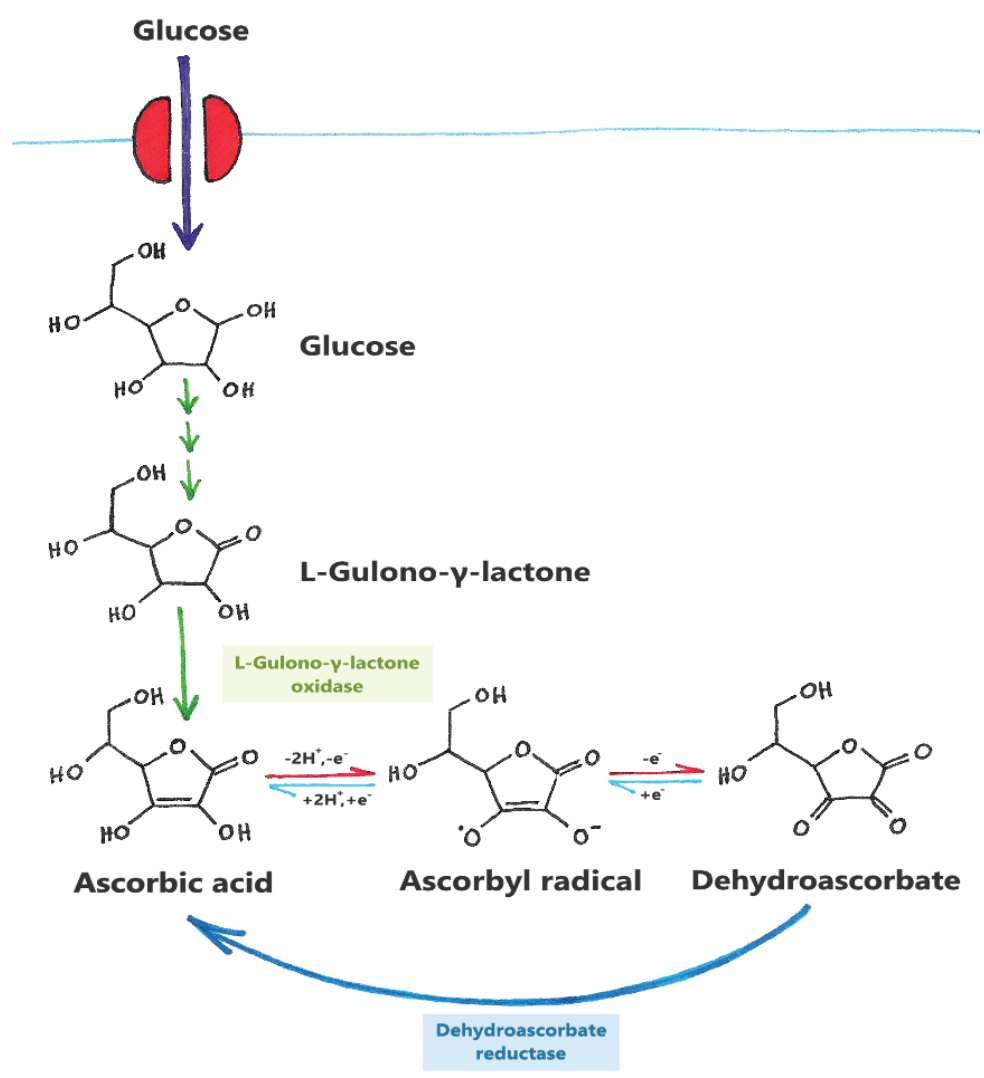

Figure 1. Simplified schematic view of vitamin $C$ biosynthesis from glucose and redox-dependent interconversion between ascorbic acid and its oxidized form dehydroascorbic acid, with the ascorbyl radical as an intermediate. 
to $90 \mathrm{mg} /$ day (National Academy of Sciences) $[9,27]$. Saturation of tissues and plasma requires a higher dosage than recommended, $100 \mathrm{mg}$ and over $500 \mathrm{mg}$ per day, respectively $[9,28]$. Doses over $500 \mathrm{mg} /$ day cannot cause any harm since half of the absorbed vitamin $C$ is eliminated from the body unmetabolized. Moreover, single doses up to $10 \mathrm{~g} /$ day in adults did not show any adverse or toxic effects in most of the studies [29]. Still, it has been known for hypersensitivity, oxalate urolithiasis, iron overload in haemochromatosis and anemia etc. to happen, but on very rare occasions [17]. However, adequate doses cannot be established since the need for vitamin $\mathrm{C}$ changes during both pathological and physiological conditions [30,31].

\section{VITAMIN C PHYSIOLOGICAL FUNCTION}

Maintaining sufficient vitamin C concentration is necessary for the occurrence of many biological processes since vitamin $C$ functions as an enzyme cofactor, a potent antioxidant, and it also has an immune function. The reducing potential of vitamin $C$ enabled its role as a cofactor of several enzymes that contain a metal ion $\left(\mathrm{Fe}^{2+}\right.$ and $\left.\mathrm{Cu}^{+}\right)$in their active site, such as monooxygenases and dioxygenases. Particularly, it maintains metal ions in a reduced ferrous $\left(\mathrm{Fe}^{2+}\right)$ and cuprous $\left(\mathrm{Cu}^{+}\right)$state, which are needed for enzyme activity. These enzymes have a role in the synthesis of collagen, carnitine, different neurotransmitters and hormones, including dopamine, norepinephrine, calcitonin, oxytocin, vasopressin, and cholecystokinin [11,32,33]. Recent studies have shown that vitamin $\mathrm{C}$ also has an important role in the epigenetic regulation as methylcytosine dioxygenases ten-eleven translocation (TET) and JmjC domain-containing histone demethylases cofactor. By contributing to the methylation/demethylation balance of histones and DNA, vitamin C is involved in the regulation of embryonic and postnatal development, aging, as well as in pathological conditions [34,35]. Ever since the role of vitamin $C$ in the prevention of scurvy has been established, numerous clinical studies have investigated its effects on human health. There has been some evidence of its protective role in cardiovascular diseases and several cancers, as well as in respiratory tract infections [9].

The fact that vitamin $C$ has a high reducing ability also makes it a potent antioxidant [36-40]. It can act directly by scavenging reactive oxygen and nitrogen species (ROS/RNS), including free radicals - hydroxyl radical, superoxide anion [41] and nitrogen dioxide [42], and nonradical species - singlet oxygen [43], hydrogen peroxide, and peroxynitrite $[40,44]$. Moreover, vitamin C activity can lead to decreasing ROS/RNS levels by inhibiting different prooxidative enzymes, including NADPH oxidase [40] and xanthine oxidase activity [41], inducible nitric oxide synthase expression [40], or by regenerating other small molecule antioxidants, like vitamin E $[39,45,46]$ and glutathione (GSH) [47]. Even though vitamin $\mathrm{C}$ is a water-soluble molecule it has a role in preventing lipid peroxidation by reducing lipidsoluble vitamin $E$ radical to its active form, vitamin $E$ (Figure 2) $[45,48,49]$. Since phospholipids build plasma membranes and membranes surrounding organelles, it is clear that vitamin $C$ is essential for maintaining cell structure. Besides its antioxidative role, vitamin $C$ may have a prooxidative effect $[39,50,51]$. However, in vivo studies showed that vitamin $C$ predominantly acts as an antioxidant in physiological conditions [36].

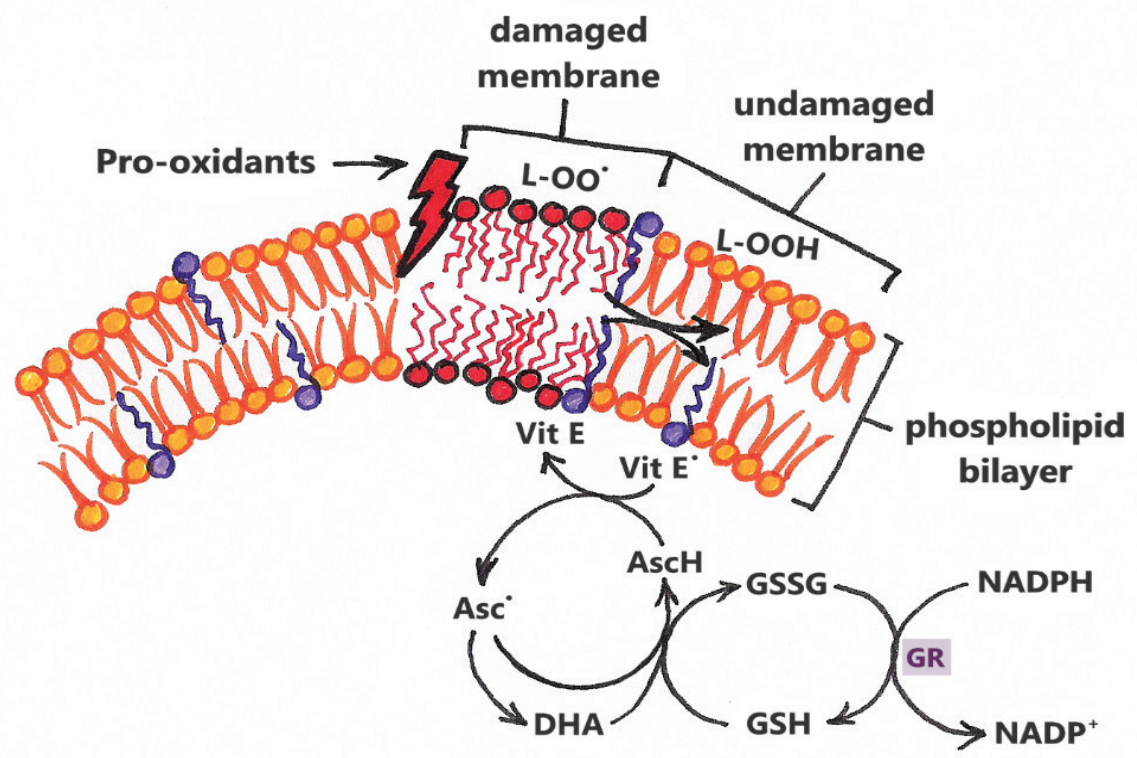

Figure 2. The cooperation between vitamin $\mathrm{C}$ and vitamin $\mathrm{E}$ in the prevention of lipid peroxidation. L-OO- lipid peroxyl radical; L-OOH - lipid peroxide; Vit E - vitamin E; Vit E' - vitamin E radical; AscH - ascorbate; AsC - ascorbyl radical; DHA - dehydroascorbate; GR - glutathione reductase. 


\section{VITAMIN C IMMUNE FUNCTION}

Even though vitamin $\mathrm{C}$ acts as a powerful antioxidant protecting tissues from various pathogens, it mainly affects components of innate and acquired immunity, acting as a cofactor for many biosynthetic enzymes and enzymes regulating gene expression [52-55]. It has been demonstrated that vitamin $C$ positively affects production [56-58] and function of leukocytes in vitro (especially lymphocytes, neutrophils, and mononuclear phagocytes), acting on cellular motility $[59,60]$, chemotaxis [61,62] and phagocytosis [55,63-66]. Moreover, vitamin C has cell-specific functions - ROS generation in neutrophils $[65,67]$, caspase-dependent apoptosis of neutrophils in macrophages $[68,69]$, thus promoting resolution of the inflammatory response, and antibody generation in lymphocytes $[55,70,71]$. Vitamin $\mathrm{C}$ also has a role in the maintenance of epithelial barriers in skin [72,73] and lungs [74] due to its contribution to collagen synthesis [75-77], wound healing [78-80], protection against ROS-induced damage $[73,81,82]$, as well as the regulation of cytoskeletal rearrangements and gene expression of tight junction proteins [74]. Additionally, vitamin C supports immune function by modulating cytokine production $[57,83-$ 85]. Although there are many benefits from increased vitamin C intake on the immune system, its role in preventing or curing diseases has not been established yet.

\section{VITAMIN C AND THE COMMON COLD}

The work of Linus Pauling put back in focus the benefits that vitamin $C$ has on human health. He suggested that vitamin $C$ mega-dose supplementation could be used to lower the incidence and severity of a condition known as the common cold $[29,86]$. The term "the common cold" is used to describe a complex condition with a large number of symptoms that do not relate to any specific disease. It is, however, usually caused by the viruses affecting different parts of the respiratory system (also known as chest, throat, and nose colds) $[87,88]$. As a response to Pauling's statement, there has been a large number of clinical studies concerning the role of vitamin $C$ in human health. Even though its beneficial effects on the duration and severity of the common cold are indisputable, it has not been proven yet that vitamin C can, in fact, be used as a preventive or therapeutic agent for the common cold [89-91]. Hemila suggested that supplemental vitamin C may lead to neutralization of reactive species in the respiratory tract generated during virus-mediated neutrophil activation, thus supporting the immune response associated with the common cold $[92,93]$. Furthermore, its antihistamine property [94] may be beneficial in reducing cold severity since histamine is responsible for the symptoms of the cold. Some clinical studies have proven that vitamin $\mathrm{C}$ supplementation ameliorates leukocyte motility (chemotaxis) [62,95], therefore also reducing the severity of cold symptoms. In addition, vitamin $\mathrm{C}$ might also have an effect on some other respiratory infections appearing as complications of colds or independently of colds [96].

Even though meta-analysis confirmed that regular supplementation with vitamin C ( 0.25 to $2 \mathrm{~g} /$ day $)$ did not reduce the common cold incidence in the general population, in six of the trials, the common cold incidence was halved in individuals experiencing short periods of extreme physical stress (e.g., marathon runners, skiers). A benefit of regular vitamin $C$ supplementation was also demonstrated regarding the duration of colds, with a greater benefit in children than in adults. Public interest in this topic continues to expand and vitamin $C$ is still being extensively used as an antiviral drug. Nevertheless, it must be noted that vitamin $C$ does not prevent nor treat the common cold $[89,90]$.

\section{SARS-COV-2 INFECTION}

Antiviral properties of vitamin $\mathrm{C}$ have once again come into question with the immersion of a novel virus from the beta coronavirus family named SARS-CoV-2. Coronaviruses of the beta genus ( $\beta$-CoVs) are enveloped, positive-sense, single-stranded RNA viruses. They predominantly infect bats, but other mammals like rodents and humans can also be their hosts [97]. Beta coronaviruses that have caused human epidemics include the Middle East Respiratory Syndrome coronavirus (MERS-CoV) [98] and Severe Acute Respiratory Syndrome coronaviruses SARS-CoV-1 [99] and SARSCoV-2 [100]. The infection caused by the virus SARSCoV-2 has been identified as Coronavirus Disease 2019 (COVID-19) [101].

SARS-CoV-2 binds to angiotensin-converting enzyme 2 (ACE2) receptor via Spike Glycoprotein (S), thus infecting lung endothelial cells (ECs) [102]. ACE2 receptors are not only present in cardiopulmonary tissues, but also in some hematopoietic cells, kidneys, and intestines $[103,104]$. This is supported by the fact that SARS-CoV-2-infected ECs were found in several organs of deceased patients [103]. Infected ECs are characterized by dysfunction, lysis, and finally, death. Moreover, ECs promote inflammation in damaged tissues by expressing leukocyte adhesion molecules [105], thus causing accumulation and extravasation of leukocytes. As a result of leukocytes activation cytokine storm occurs $[106,107]$. After being recruited to the lungs, activated neutrophils and macrophages also generate excessive reactive oxygen and nitrogen species. On the one hand, ROS and RNS regulate immune response by oxidant-induced activation of transcription factors responsible for the expression of inflammatory cytokines and chemokines. On the other hand, ROS can act as 
oxidants, damaging both virus cells and lung (heart) cells, hence further promoting ECs malfunction and finally lung tissue damage $[108,109]$.

In the cases of severe endothelial cell damage, the loss of microvascular barrier function occurs in the lungs resulting in enhanced vascular permeability. In addition, the binding of SARS-CoV-2 to the ACE2 receptor prevents ACE2 from degrading angiotensin II, thus affecting the angiotensin-vasopressor system. Reduced ACE2 activity also leads to increased vascular permeability [110]. Furthermore, immune cells, inflammatory cytokines, and vasoactive molecules promote enhanced EC contractility. As a consequence of these events, fluid leaks and fills alveolar sacks [105]. Finally, the cytokines IL-1 $\beta$ and TNF stimulate fluid retention (pulmonary edema) in the lungs. All of these symptoms - ECs malfunction, inflammation, vasodilatation, forming of the blood clots are being amplified by the high levels of cytokines, which are constantly being produced as a response to the virus infection [110].

Clinical manifestations of the COVID-19 can vary from asymptomatic to severe pneumonia [111-113]. When the body's response to infection causes injury to its own tissues and organs, sepsis occurs. The most common infectious source of sepsis is indeed pneumonia [114]. Alveolar dysfunction and consequential severe lung injury lead to acute respiratory distress syndrome (ARDS) and septic shock, followed by multiple organ failure and very often death $[112,115]$. ARDS as a form of fluid accumulation in the lungs prevents necessary oxygen from entering the lungs, ultimately causing hypoxic respiratory failure [116]. Hence, ARDS and septic shock are the main cause of ICU care and mortality in COVID-19 patients, as well as concurrent pathological conditions, including hypertension, cardiovascular and cerebrovascular diseases, and diabetes $[111,112,115]$.

\section{COVID-19 TREATMENT}

Being that SARS-CoV-2 is genetically similar to SARSCoV-1 [117], previously described pathological symptoms in patients suffering from COVID-19 are also similar to the one of SARS $[111,118]$. However, in comparison to SARS-CoV-1, SARS-CoV-2 has higher transmissibility and infectivity. Moreover, patients with COVID-19 have a longer incubation period, therefore explaining the rapid expansion of the SARS-CoV-2 virus $[119,120]$. The COVID-19 pandemic has been spreading to many continents and countries since it was first reported in December of 2019, henceforth causing a public health emergency $[101,121]$. Numerous clinical trials concerning COVID-19 are in effect. However, an effective cure for the disease is yet to be found, with the main current treatment being the symptomatic one. Besides oxygen therapy, some of the treatments for severe cases of
COVID-19 also include several antiviral drugs, normally used against other viruses, in combination with interferon $[113,116,122,123]$. Nonetheless, further studies concerning vaccines and/or antiviral drugs are necessary since these are all temporary solutions with no confirmed competence in the treatment of COVID-19.

The hypothesis that vitamin $\mathrm{C}$ may be beneficial in the treatment of COVID-19 is supported by the data showing its well-established role as an imperative medicament against various viral infections [91,124]. What is more important, vitamin $\mathrm{C}$ is a very safe biomolecule, and it can be used in massive dosages with the exception of those suffering from glucose-6-phosphate dehydrogenase (G6PD) deficiency $[125,126]$, hemochromatosis [127], or renal insufficiency $[128,129]$. As previously mentioned, multiple placebo-controlled trials have shown that the duration and severity of common cold were reduced in the vitamin C groups, suggesting that the viral respiratory infections in humans are affected by vitamin $\mathrm{C}$ levels. There is also data from controlled trials with human subjects suggesting that vitamin C may lower susceptibility to pneumonia $[91,130]$. Despite the well-known beneficial effect of vitamin $C$ in viral infections, there is still no solid clinical data confirming the in vivo virucidal activity of vitamin C. Considering the possibility that vitamin $\mathrm{C}$ may affect severe viral respiratory tract infections as well, there are currently many ongoing studies examining its effect and possible applications against COVID-19.

Normal vitamin C plasma level of around $50 \mu \mathrm{mol} / \mathrm{l}$ in adults is not enough to prevent viral infections and physiological stress. Moreover, in hospitalized patients suffering mostly from acute respiratory infections, sepsis or severe COVID-19 metabolic consumption of vitamin $C$ is increased, and its plasma level drastically declines $(\leq 11 \mu \mathrm{mol} / \mathrm{l})$ [131-135]. This occurs as a consequence of highly enhanced inflammation and oxidation caused by ROS/RNS, which is why these patients require high dosage vitamin C supplementation $[83,136]$. Due to the limited enteral absorption of vitamin $\mathrm{C}$ by oral intake (maximum plasmatic levels around 220 $\mu \mathrm{mol} / \mathrm{l}$ ) [137], therapeutic effects can be achieved only by high dosage intravenous administration of vitamin C (HD-IVC), leading to its rapid increase in the blood (plasmatic levels up to $20-49 \mathrm{mmol} / \mathrm{l}$ ) [138]. The results of one study [139] suggest that the early use of HDIVC in combination with hydrocortisone and thiamine (HAT therapy) may prevent progressive organ dysfunction and reduce the mortality of patients with severe sepsis and septic shock. Studies have shown that the therapeutic effect of vitamin $\mathrm{C}$ here is based on its immunosuppressive capacity through down-regulation of the production of the proinflammatory cytokines, enabling protection of alveolar epithelial barrier from inflammatory damage, and through the increase of the $\alpha / \beta$ interferon production $[85,116,140-142]$. Inhibition 
of the cytokine storm progression is achieved by attenuation of nuclear factor kappa-B (NFkB) activation [143-145]. This is confirmed in a study examining the levels of IL- 6 and tumor necrosis factor alpha (TNF-a) production in hospitalized patients suffering from pneumonia [83]. Furthermore, it has been shown that vitamin $C$ suppresses acute lung injury by multiple mechanisms, including enhancement of the epithelial barrier function and regulation of the alveolar fluid clearance through increased synthesis and/or activity of ion channels and pumps [74]. Meta-analyses also demonstrated that vitamin $\mathrm{C}$ may have a vasopressor sparing effect and that it may shorten the duration of mechanical ventilation [146]. The CITRIS-ALI Randomized Clinical Trial [147] has shown that HD-IVC can successfully reduce mortality and ICU stay in patients with sepsis and ARDS. What is more important, it has been reported that HD-IVC was generally well tolerated in clinical trials with no adverse effect $[89,129,148]$.

Based on all of these observations, numerous clinical trials examining the effect of HD-IVC administration as a treatment for COVID-19 were highly encouraged. Although oral vitamin C supplementation does not help in the critical COVID-19 cases, it has been suggested that oral dose (2-8 g/day) may attenuate the conversion from mild to the critical COVID-19 infection [149]. On the other hand, HD-IVC administration was shown to have a beneficial effect in the critical COVID-19 cases. There is an urgent need to examine the uses of HD-IVC pre-, post-, and during different stages of the COVID-19 infection. The following preliminary results were reported: HD-IVC seems to significantly reduce the inflammation, ICU, and hospital stays of COVID-19 patients [150]. Nevertheless, more research is needed to confirm the clinical efficacy and safety of HD-IVC administration in the treatment of COVID-19 before its official approval as an applicable medicament.

\section{POSSIBLE MECHANISMS OF VITAMIN C ACTION IN COVID-19}

Vitamin C has been extensively used against many other diseases like the common cold [90], and other viral infections, cancer $[151,152]$, diabetes $[153,154]$, heart disease [155], etc. Several proven mechanisms underlying the role of vitamin $C$ in the treatment and/or prevention of previously mentioned diseases include enhancement of the immune system, prevention of the free radical damage (antioxidant role), inhibition of the excessive activation of the immune system, and consequential prevention of tissue damage, the formation of the epithelial and endothelial barrier. Vitamin C, along with other micronutrients (zinc, selenium, magnesium, vitamin A, D, and E) [156-158], glutathione [159,160], and omega-3 fatty acids [161], is considered to be one of the leading antiviral co-therapy targeting SARSCoV-2. While the positive effects of vitamin $C$ were recognized, its mechanism of action remains unknown. An important question has been raised here - does HD-IVC act as a therapeutic agent against SARS-CoV-2 in some of the previously described ways or does it act in some other way? In the case of HD-IVC, its mechanism of action is usually carried out by $\mathrm{H}_{2} \mathrm{O}_{2}$. There are two potential pathways - one of them involves the cytotoxic effect of $\mathrm{H}_{2} \mathrm{O}_{2}$, as seen in tumor cells induced by HD-IVC, and the other one suggests changes in metabolism and energetic homeostasis, again via increase in $\mathrm{H}_{2} \mathrm{O}_{2}$ level (Figure 3).

A similar therapeutic approach, i.e., HD-IVC in cancer therapy, may point to the prooxidant property of vitamin $C$ as a potential mechanism of vitamin $C$ action in SARS-CoV-2. Parenteral administration of HD-IVC neglects tight control, leading to $\mathrm{H}_{2} \mathrm{O}_{2}$ formation in a distinct point of time $[151,152,162,163] . \mathrm{H}_{2} \mathrm{O}_{2}$ in the blood is immediately eliminated by catalase $[164,165]$, while

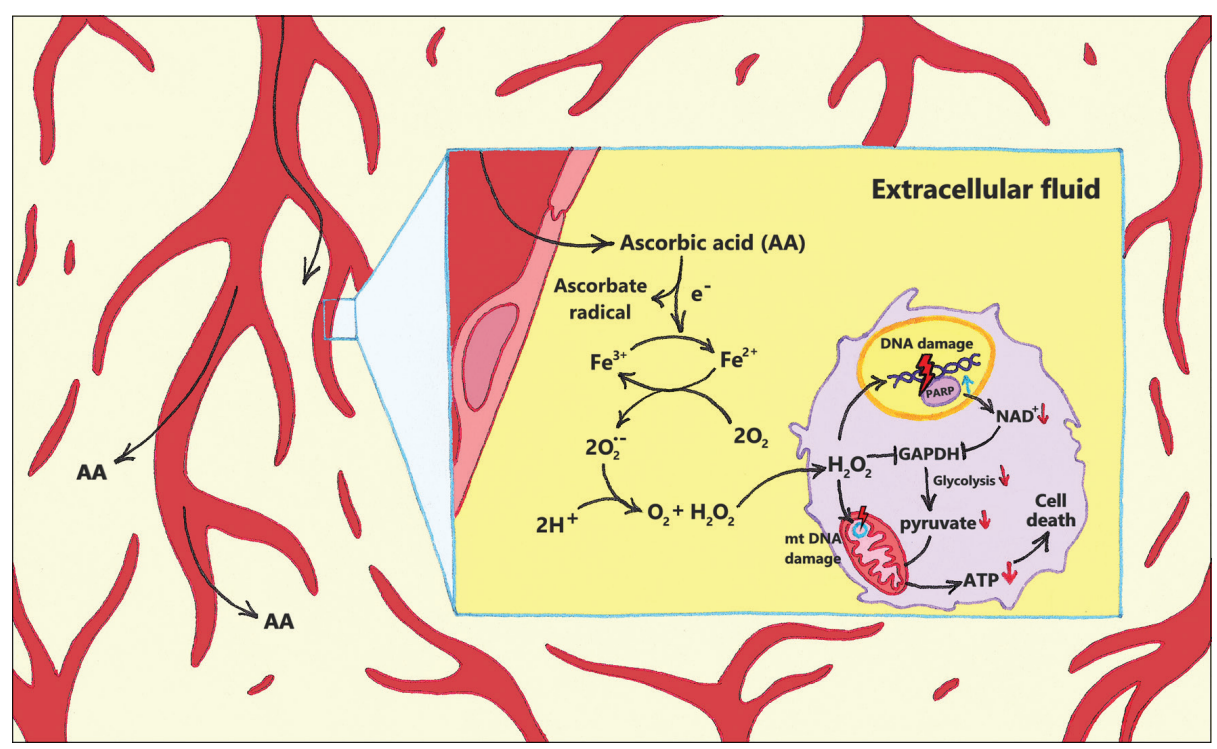

Figure 3. Proposed mechanisms of HD-IVC effect through hydrogen-peroxide-dependent pathway. GAPDH - Glyceraldehyde 3-phosphate dehydrogenase; PARP - poly (ADP-ribose) polymerase. Adapted from [151,152]. 
$\mathrm{H}_{2} \mathrm{O}_{2}$ present in extracellular fluid enters the cells. Due to different preferential energetic metabolism known as Warburg effect [166-168] $\mathrm{H}_{2} \mathrm{O}_{2}$ displays cell-dependent cytotoxicity. Oxidative stressinduced by pharmacological concentrations of vitamin C causes DNA damage and inhibits glycolysis in susceptible cancer cells, leading to their death $[151,152]$. That is because cancer cells highly depend on glycolysis for their ATP production. Unlike cancer cells, the main source of ATP production in normal cells is mitochondrial oxidative phosphorylation, hence explaining why glycolysis inhibition does not affect them as much [151]. One of the proposed mechanisms of glycolysis inhibition is through DNA damage induced by $\mathrm{H}_{2} \mathrm{O}_{2}$, which in turn activates poly (ADP-ribose) polymerase (PARP). PARP depletes $\mathrm{NAD}^{+}$, and depletion of $\mathrm{NAD}^{+}$leads to inhibition of glyceraldehyde 3-phosphate dehydrogenase (GAPDH) activity [169]. Being that GAPDH is a crucial glycolytic enzyme, glycolysis is inhibited and ATP levels are reduced $[151,152]$. Another possible way of ATP depletion is direct damage of mitochondrial ATP synthase by $\mathrm{H}_{2} \mathrm{O}_{2}$ and/or degradation of $\mathrm{H}_{2} \mathrm{O}_{2}$ by concurrent oxidation of GSH to GSSG $[170,171]$.

Considering glycolysis is also thought to be the main energy source for the immune effector cells [166], HD-IVC administration might also have a prooxidant effect on the immune effector cells, thus downregulating proinflammatory mediator expression and improving alveolar fluid clearance during SARS-CoV-2 infection [172]. Moreover, lung ECs, just like any other normal cell type, mostly depend on mitochondrial oxidative phosphorylation for ATP production, which is why HD-IVC should act as an antioxidant in the lung ECs, enhancing their function [74]. Still, intravenous glucocorticoid treatment is proposed to be taken together with HD-IVC to reduce possible inflammation caused by osmotic death of the immune effector cells [172]. Nevertheless, there is currently no evidence pointing to the cytotoxic effect of vitamin C pharmacological concentrations in the treatment of COVID-19 infection.

\section{CONCLUSION AND PERSPECTIVE}

In the paper from 1996 [39] Barry Halliwell, after an extraordinary analysis of the biological effects of vita$\min C$ and its antioxidant and prooxidant effects, postulates: "Ascorbate is essential in the human diet, but many unanswered questions remain." Further, the website of the Linus Pauling Institute, which promotes his work and healthy nutrition, states: "There is currently no data available to show that vitamin $C$ can prevent or successfully treat COVID-19 infections" (https://lpi. oregonstate.edu/COVID19/ vitamin-c-and-COVID-19).

On the other hand, we have witnessed for a long time, and even today, that vitamin $C$ is the most frequently used supplement. Historically, just like aspirin.
In health and disease. Even today in the epidemic of COVID-19, regardless of the method, amount, and duration of supplementation. We could say it is reborn as a Phoenix, or perhaps it is more correct to say that vitamin C is continuously a Phoenix. A redox Phoenix, used even before we knew about it, and always before discovering the mechanisms of its action in vivo.

\section{ACKNOWLEDGMENTS}

The authors are grateful for the support from the Ministry of Education, Science and Technological Development of the Republic of Serbia [grant numbers 451-0368/2020-14/200007 and 451-03-68/2020-14/200178].

\section{REFERENCES}

1. Raizman N. Scurvy: How a surgeon, a mariner, and a gentleman solved the greatest medical mystery of the age of sail. J Clin Invest. 2004;114(12):1690-1690.

2. Carpenter KJ. The History of Scurvy and Vitamin C. J Hist Med. 1987;42:386-7.

3. Hemilä H. A brief history of vitamin $\mathrm{C}$ and its deficiency, scurvy. 2012;1-15. Available from: https://www. mv.helsinki.fi/home/hemila/history/

4. Carpenter KJ. The discovery of vitamin c. Ann Nutr Metab. 2012;61(3):259-64.

5. Szent-Györgyi A. Observations on the function of peroxidase systems and the chemistry of the adrenal cortex: description of a new carbohydrate derivative. Biochem J. 1928;22(6):1387-409.

6. Svirbely JL, Szent-Györgyi A. Hexuronic acid as the antiscorbutic factor. Nature. 1932;129(3262):690.

7. King CG, Waugh WA. The isolation and identification of vitamin C. J Biol Chem. 1932;97(1):325-31.

8. Ault RG, Baird DK, Carrington HC, Haworth WN, Herbert R, Hirst EL, et al. Synthesis of d- and of I-Ascorbic Acid and of Analogous Substances. J Chem Soc. 1933;141923.

9. Schlueter AK, Johnston CS. Vitamin C: Overview and update. J Evid Based Complementary Altern Med. 2011;16(1):49-57.

10. Buettner GR, Jurkiewicz BA. Catalytic metals, ascorbate and free radicals: Combinations to avoid. Radiat Res. 1996;145(5):532-41.

11. Englard S, Seifter S. The Biochemical functions of ascorbic acid. Annu Rev Nutr. 1986;6:365-406.

12. Park JB, Levine M. Purification, cloning and expression of dehydroascorbic acid-reducing activity from human neutrophils: Identification as glutaredoxin. Biochem J. 1996;315(3):931-8.

13. May JM, Cobb CE, Mendiratta S, Hill KE, Burk RF. Reduction of the ascorbyl free radical to ascorbate by thioredoxin reductase. J Biol Chem. 1998;273(36):23039-45.

14. Linster CL, Van Schaftingen E. Vitamin C: Biosynthesis, recycling and degradation in mammals. FEBS J. 2007;274(1):1-22.

15. May JM. Vitamin C transport and its role in the central nervous system. Subcell Biochem. 2012;56:85-103. 
16. Nishikimi M, Fukuyama R, Minoshima S, Shimizu N, Yagi $\mathrm{K}$. Cloning and chromosomal mapping of the human nonfunctional gene for L- gulono-p-lactone oxidase, the enzyme for L-ascorbic acid biosynthesis missing in man. J Biol Chem. 1994;269(18):13685-8.

17. Levine M, Rumsey SC, Daruwala R, Park JB, Wang Y. Criteria and recommendations for vitamin C intake. J Am Med Assoc. 1999;281(15):1415-23.

18. Lykkesfeldt J, Tveden-Nyborg P. The pharmacokinetics of vitamin C. Nutrients. 2019;11(10).

19. Malo C, Wilson JX. Glucose modulates vitamin C transport in adult human small intestinal brush border membrane vesicles. J Nutr. 2000;130(1):63-9.

20. Goldenberg H, Schweinzer E. Transport of vitamin $C$ in animal and human cells. J Bioenerg Biomembr. 1994;26(4):359-67.

21. Wilson JX. Regulation of vitamin C transport. Annu Rev Nutr. 2005;25:105-25.

22. Michels AJ, Hagen TM, Frei B. Human genetic variation influences vitamin c homeostasis by altering vitamin $C$ transport and antioxidant enzyme function. Annu Rev Nutr. 2013;33:45-70.

23. Tsukaguchi $H$, Tokui T, Mackenzie B, Berger U V., Chen $X-Z$, Wang $Y$, et al. A family of mammalian $\mathrm{Na}$ +-dependent L-ascorbic acid transporters. Nature. 1999;399:70-5.

24. Rumsey SC, Kwon O, Xu GW, Burant CF, Simpson I, Levine M. Glucose transporter isoforms GLUT1 and GLUT3 transport dehydroascorbic acid. J Biol Chem. 1997;272(30):18982-9.

25. Corpe $\mathrm{CP}$, Eck P, Wang J, Al-Hasani H, Levine M. Intestinal dehydroascorbic acid (DHA) transport mediated by the facilitative sugar transporters, GLUT2 and GLUT8. J Biol Chem. 2013;288(13):9092-101.

26. Korcok J, Dixon SJ, Lo TCY, Wilson JX. Differential effects of glucose on dehydroascorbic acid transport and intracellular ascorbate accumulation in astrocytes and skeletal myocytes. Brain Res. 2003;993:201-7.

27. Institute of Medicine. Dietary reference intakes for vitamin C, vitamin E, selenium, and carotenoids. Washington, D.C.: National Academy Press; 2000.

28. Levine M, Conry-Cantilena C, Wang Y, Welch RW, Washko PW, Dhariwal KR, et al. Vitamin C pharmacokinetics in healthy volunteers: Evidence for a recommended dietary allowance. Proc Natl Acad Sci U S A. 1996;93(8):3704-9.

29. Pauling L. Vitamin C and the common cold. San Francisco: W. H. Freeman and Company; 1970.

30. Carr AC, Frei B. Toward a new recommended dietary allowance for vitamin $C$ based on antioxidant and health effects in humans. Am J Clin Nutr. 1999;69(6):1086-107.

31. Brubacher D, Moser U, Jordan P. Vitamin C concentrations in plasma as a function of intake: A meta-analysis. Int J Vitam Nutr Res. 2000;70(5):226-37.

32. Levine M. New concepts in the biology and biochemistry of ascorbic acid. N Engl J Med. 1986;314(14):892902.

33. Carr AC, Shaw GM, Fowler AA, Natarajan R. Ascorbatedependent vasopressor synthesis: A rationale for vitamin C administration in severe sepsis and septic shock? Crit Care. 2015;19(418):1-8.

34. Camarena V, Wang $\mathrm{G}$. The epigenetic role of vitamin $\mathrm{C}$ in health and disease. Cell Mol Life Sci. 2016;73(8):164558.
35. Young Jl, Züchner S, Wang G. Regulation of the Epigenome by Vitamin C. Annu Rev Nutr. 2015;35(1):545-64.

36. Carr A, Frei B. Does vitamin $C$ act as a prooxidant under physiological conditions? FASEB J. 1999;13(9):1007-24.

37. Frei B, Stocker R, England L, Ames BN. Ascorbate: The most effective antioxidant in human blood plasma. Antioxidants Ther Prev Med. 1990;155-63.

38. Frei B, England L, Ames BN. Ascorbate is an outstanding antioxidant in human blood plasma. Proc Natl Acad Sci U S A. 1989;86:6377-81.

39. Halliwell B. Vitamin C: Antioxidant or prooxidant in vivo? Free Radic Res. 1996;25(5):439-54.

40. Oudemans-van Straaten HM, Spoelstra-de Man AME, de Waard MC. Vitamin C revisited. Crit Care. 2014;18(460):1-13.

41. Nishikimi M. Oxidation of ascorbic acid with superoxide anion generated by the xanthine-xanthine oxidase system. Biochem Biophys Res Commun. 1975;63(2):463-8.

42. Cooney R V, Ross PD, Bartolini GL. N-nitrosation and Nnitration of morpholine by nitrogen dioxide: Inhibition by ascorbate, glutathione and a-tocopherol. Cancer Lett. 1986;32:83-90.

43. Chou PT, Khan AU. L-ascorbic acid quenching of singlet delta molecular oxygen in aqueous media: Generalized antioxidant property of vitamin C. Biochem Biophys Res Commun. 1983;115(3):932-7.

44. Bartlett, D., Church, D., Bounds, P., Koppenol W. The Kinetics of the Oxidation of L-Ascorbic Acid by Peroxynitrite. Free Radic Biol Med. 1995;18(1):85-92.

45. Buettner GR. The pecking order of free radicals and antioxidants: lipid peroxidation, a-tocopherol, and ascorbate. Archives of biochemistry and biophysics. 1993;300(2):535-43.

46. McCay PB. Vitamin E: interactions with free radicals and ascorbate. Annu Rev Nutr. 1985;5:323-40.

47. Meister A. Glutathione-ascorbic acid antioxidant system in animals. J Biol Chem. 1994;269(13):9397-400.

48. Neužil J, Thomas SR, Stocker R. Requirement for, promotion, or inhibition by a-tocopherol of radical- induced initiation of plasma lipoprotein lipid peroxidation. Free Radic Biol Med. 1997;22(1-2):57-71.

49. Bowry VW, Mohr D, Cleary J, Stocker R. Prevention of tocopherol-mediated peroxidation in ubiquinol10-free human low density lipoprotein. J Biol Chem. 1995;270(11):5756-63.

50. Podmore ID, Griffiths HR, Herbert KE, Mistry N, Mistry P, Lunec J. Vitamin C exhibits prooxidant properties. Nature. 1998;392(6676):559.

51. Mandl J, Szarka A, Bánhegyi G. Vitamin C: Update on physiology and pharmacology. Br J Pharmacol. 2009;157(7):1097-110.

52. Carr AC, Maggini S. Vitamin $C$ and immune function. Nutrients. 2017;9(11):1-25.

53. Maggini S, Wintergerst ES, Beveridge S, Hornig DH. Selected vitamins and trace elements support immune function by strengthening epithelial barriers and cellular and humoral immune responses. $\mathrm{Br} J$ Nutr. 2007;98:29-35.

54. Webb AL, Villamor E. Update: Effects of antioxidant and non-antioxidant vitamin supplementation on immune function. Nutr Rev. 2007;65(5):181-217.

55. Leibovitz B, Siegel B V. Ascorbic acid and the immune response. Diet Resist to Dis. 1981;135:1-25. 
56. Huijskens MJAJ, Walczak M, Koller N, Briedé JJ, Senden-Gijsbers BLMG, Schnijderberg MC, et al. Technical Advance: Ascorbic acid induces development of double-positive $T$ cells from human hematopoietic stem cells in the absence of stromal cells. J Leukoc Biol. 2014;96:1165-75.

57. Molina N, Morandi AC, Bolin AP, Otton R. Comparative effect of fucoxanthin and vitamin $C$ on oxidative and functional parameters of human lymphocytes. Int Immunopharmacol. 2014;22:41-50.

58. Manning J, Mitchell B, Appadurai DA, Shakya A, Pierce $\mathrm{LJ}$, Wang $\mathrm{H}$, et al. Vitamin $\mathrm{C}$ promotes maturation of $\mathrm{T}$ cells. Antioxidants Redox Signal. 2013;19(17):2054-67.

59. Anderson $\mathrm{R}$, Theron A. Effects of ascorbate on leucocytes: Part III. In vitro and in vivo stimulation of abnormal neutrophil motility by ascorbate. South African Med J. 1979;56:429-33.

60. Anderson R. Ascorbate-mediated stimulation of neutrophil motility and lymphocyte transformation by inhibition of the peroxidase/ $/ \mathrm{H} 2 \mathrm{O} 2 /$ halide system in vitro and in vivo. Am J Clin Nutr. 1981;34:1906-11.

61. Johnston CS, Huang S. Effect of ascorbic acid nutriture on blood histamine and neutrophil chemotaxis in guinea pigs. J Nutr. 1991;121:126-30.

62. Johnston CS, Martin LJ, Cai X. Antihistamine effect of supplemental ascorbic acid and neutrophil chemotaxis. Journal of the American College of Nutrition. 1992;11(2):172-6.

63. De La Fuente M, Ferrández MD, Burgos MS, Soler A, Prieto $A$, Miquel J. Immune function in aged women is improved by ingestion of vitamins $\mathrm{C}$ and $\mathrm{E}$. Can J Physiol Pharmacol. 1998;76:373-80.

64. Ganguly R, Durieux M-F, Waldman RH. Macrophage function in vitamin C-deficient guinea pigs. Am J Clin Nutr. 1976;29:762-5.

65. Levy R, Shriker O, Porath A, Riesenberg K, Schlaeffer F. Vitamin $C$ for the treatment of recurrent furunculosis in patients with impaired neutrophil functions. J Infect Dis. 1996;173:1502-5

66. Shilotri PG. Phagocytosis and leukocyte enzymes in ascorbic acid deficient guinea pigs. J Nutr. 1977;107:1513-6.

67. Bozonet SM, Carr AC, Pullar JM, Vissers MCM. Enhanced human neutrophil vitamin $C$ status, chemotaxis and oxidant generation following dietary supplementation with vitamin C-rich SunGold kiwifruit. Nutrients. 2015;7:2574-88.

68. Sharma P, Raghavan SAV, Saini R, Dikshit M. Ascorbatemediated enhancement of reactive oxygen species generation from polymorphonuclear leukocytes: modulatory effect of nitric oxide. J Leukoc Biol. 2004;75:1070-8.

69. Vissers MCM, Wilkie RP. Ascorbate deficiency results in impaired neutrophil apoptosis and clearance and is associated with up-regulation of hypoxia-inducible factor 1a. J Leukoc Biol. 2007;81:1236-44.

70. Tanaka M, Muto N, Gohda E, Yamamoto I. Enhancement by Ascorbic Acid 2-Glucoside or Repeated Additions of Ascorbate of Mitogen-Induced IgM and IgG Productions by Human Peripheral Blood Lymphocytes. Jpn J Pharmacol. 1994;66:451-6.

71. Feigen GA, Smith BH, Dix CE, Flynn CJ, Peterson NS, Rosenberg LT, et al. Enhancement of antibody production and protection against systemic anaphylaxis by large doses of vitamin C. Res Commun Chem Pathol Pharmacol. 1982;38:313-33.
72. Pullar JM, Carr AC, Vissers MCM. The roles of vitamin C in skin health. Nutrients. 2017;9(866):1-27.

73. Lauer AC, Groth N, Haag SF, Darvin ME, Lademann J, Meinke MC. Dose-dependent vitamin C uptake and radical scavenging activity in human skin measured with in vivo electron paramagnetic resonance spectroscopy. Skin Pharmacol Physiol. 2013;26:147-54.

74. Fisher BJ, Kraskauskas D, Martin EJ, Farkas D, Wegelin JA, Brophy $D$, et al. Mechanisms of attenuation of abdominal sepsis induced acute lung injury by ascorbic acid. Am J Physiol - Lung Cell Mol Physiol. 2012;303:20-32.

75. Kishimoto Y, Saito N, Kurita K, Shimokado K, Maruyama $\mathrm{N}$, Ishigami A. Ascorbic acid enhances the expression of type 1 and type 4 collagen and SVCT2 in cultured human skin fibroblasts. Biochem Biophys Res Commun. 2013;430:579-84.

76. Tajima S, Pinnell SR. Ascorbic acid preferentially enhances type I and III collagen gene transcription in human skin fibroblasts. J Dermatol Sci. 1996;11:250-3.

77. Davidson JM, LuValle PA, Zoia O, Quaglino D, Giro M. Ascorbate differentially regulates elastin and collagen biosynthesis in vascular smooth muscle cells and skin fibroblasts by pretranslational mechanisms. J Biol Chem. 1997;272:345-52.

78. Mohammed BM, Fisher BJ, Kraskauskas D, Ward S, Wayne JS, Brophy DF, et al. Vitamin C promotes wound healing through novel pleiotropic mechanisms. Int Wound J. 2016;13(4):572-84.

79. Desneves KJ, Todorovic BE, Cassar A, Crowe TC. Treatment with supplementary arginine, vitamin $C$ and zinc in patients with pressure ulcers: A randomized controlled trial. Clin Nutr. 2005;24:979-87.

80. Cereda E, Gini A, Pedrolli C, Vanotti A. Disease-specific, versus standard, nutritional support for the treatment of pressure ulcers in institutionalized older adults: A randomized controlled trial. J Am Geriatr Soc. 2009;57:1395402.

81. Valacchi G, Sticozzi C, Belmonte G, Cervellati F, Demaude J, Chen $\mathrm{N}$, et al. Vitamin $\mathrm{C}$ compound mixtures prevent ozone-induced oxidative damage in human keratinocytes as initial assessment of pollution protection. PLoS One. 2015;10(8):1-15.

82. Valacchi G, Muresan XM, Sticozzi C, Belmonte G, Pecorelli A, Cervellati F, et al. Ozone-induced damage in 3D-Skin Model is prevented by topical vitamin C and vitamin E compound mixtures application. J Dermatol Sci. 2016; 82(3):209-12.

83. Chen $Y$, Luo G, Yuan J, Wang Y, Yang X, Wang $X$, et al. Vitamin $C$ Mitigates Oxidative Stress and Tumor Necrosis Factor-Alpha in Severe Community-Acquired Pneumonia and LPS-Induced Macrophages. Mediators Inflamm. 2014;2014:1-11.

84. Jeng KCG, Yang CS, Siu WY, Tsai YS, Liao WJ, Kuo JS. Supplementation with vitamins $C$ and $E$ enhances cytokine production by peripheral blood mononuclear cells in healthy adults. Am J Clin Nutr. 1996;64:960-5.

85. Kim Y, Kim H, Bae S, Choi J, Lim SY, Lee N, et al. Vitamin $C$ Is an Essential Factor on the Anti-viral Immune Responses through the Production of Interferon- $\alpha / \beta$ at the Initial Stage of Influenza A Virus (H3N2) Infection. Immune Netw. 2013;13(2):70-4.

86. Pauling L. Ascorbic acid the common cold. Am J Clin Nutr. 1971;24:1294-9. 
87. Elwood PC, Lee HP, St Leger AS, McLean Baird I, Howard AN. A randomized controlled trial of vitamin $C$ in the prevention and amelioration of the common cold. $\mathrm{Br} \mathrm{J}$ Prev Soc Med. 1976;30:193-6.

88. Hemilä $\mathrm{H}$. Vitamin $\mathrm{C}$ intake and susceptibility to the common cold. Br J Nutr. 1997;77:59-72.

89. Hemilä H, Chalker E. Vitamin C for preventing and treating the common cold. Cochrane Database Syst Rev. 2013; (1):CD000980.

90. Douglas R, Hemilä H, Chalker E, D'Souza R, Treacy B. Vitamin $C$ for preventing and treating the common cold. Cochrane Database Syst Rev. 2004;(4):CD000980.

91. Hemilä H. Vitamin C and infections. Nutrients. 2017;9(339):1-28.

92. Hemilä H. Vitamin C and the common cold. Br J Nutr. 1992;67:3-16.

93. Hemilä H. Vitamin C, neutrophils and the symptoms of the common cold. Pediatr Infect Dis J. 1997;11(9):779.

94. Johnston CS. The Antihistamine Action of Ascorbic Acid. Subcell Biochem. 1996;25:189-213.

95. Boxer LA, Vanderbilt B, Bonsib S, Jersild R, Yang H, Baehner RL. Enhancement of Chemotactic Response and Microtubule Assembly in Human Leukocytes by Ascorbic Acid. J Cell Physiol. 1979;100:119-26.

96. Hemilä $\mathrm{H}$, Douglas RM. Vitamin $\mathrm{C}$ and acute respiratory infections. Int J Tuberc Lung Dis. 1999;3(9):756-61.

97. Loeffelholz MJ, Hodinka RL, Young SA, Pinsky BA. Clinical Virology Manual Fifth Edition. 2016.

98. Zaki AM, Boheemen S van, Bestebroer TM, Osterhaus ADME, Fouchier RAM. Isolation of a Novel Coronavirus from a Man with Pneumonia in Saudi Arabia. N Engl J Med. 2012;367:1814-20.

99. Ksiazek TG, Erdman D, Goldsmith CS, Zaki SR, Peret T, Emery $\mathrm{S}$, et al. A Novel Coronavirus Associated with Severe Acute Respiratory Syndrome. N Engl J Med. 2003;348(20):1953-66.

100. Peeri NC, Shrestha N, Rahman SM, Zaki R, Tan Z, Bibi $S$, et al. The SARS, MERS and novel coronavirus (COVID-19) epidemics, the newest and biggest global health threats: what lessons have we learned? Int J Endocrinol. 2020;1-10.

101. Zhu N, Zhang D, Wang W, Li X, Yang B, Song J, et al. A Novel Coronavirus from Patients with Pneumonia in China, 2019. N Engl J Med. 2020;382:727-33.

102. Hoffmann $M$, Kleine-Weber $H$, Schroeder $S$, Kruger $N$, Herrler T, Erichsen S, et al. SARS-CoV-2 Cell Entry Depends on ACE2 and TMPRSS2 and Is Blocked by a Clinically Proven Protease Inhibitor. Cell. 2020;181(2):271280.

103. Varga Z, Flammer AJ, Steiger $P$, Haberecker $M, A n-$ dermatt $R$, Zinkernagel $A S$, et al. Endothelial cell infection and endotheliitis in COVID-19. Lancet. 2020;395(10234):1417-8.

104. Zou X, Chen K, Zou J, Han P, Hao J, Han Z. Single-cell RNA-seq data analysis on the receptor ACE2 expression reveals the potential risk of different human organs vulnerable to 2019-nCoV infection. Front Med. 2020;14(2):185-92.

105. Pober JS, Sessa WC. Evolving functions of endothelial cells in inflammation. Nat Rev Immunol. 2007;7(10):803-15.

106. Bhaskar S, Sinha A, Banach M, Mittoo S, Weissert R, Kass JS, et al. Cytokine Storm in COVID-19-Immunopatho- logical Mechanisms, Clinical Considerations, and Therapeutic Approaches: The REPROGRAM Consortium Position Paper. Front Immunol. 2020;11(1648).

107. Moore JB, June $\mathrm{CH}$. Cytokine release syndrome in severe COVID-19. Science. 2020;368(6490):473-4.

108. Cecchini R, Cecchini AL. SARS-CoV-2 infection pathogenesis is related to oxidative stress as a response to aggression. Med Hypotheses. 2020;143(110102).

109. Laforge $M$, Elbim $C$, Frère $C$, Hémadi $M$, Massaad $C$, Nuss $P$, et al. Tissue damage from neutrophil-induced oxidative stress in COVID-19. Nat Rev Immunol. 2020;20:515-6.

110. Teuwen LA, Geldhof V Pasut A, Carmeliet P. COVID-19: the vasculature unleashed. Nat Rev Immunol. 2020;20:389-91.

111. Huang C, Wang Y, Li X, Ren L, Zhao J, Hu Y, et al. Clinical features of patients infected with 2019 novel coronavirus in Wuhan, China. Lancet. 2020;395(10223):497-506.

112. Chen N, Zhou M, Dong X, Qu J, Gong F, Han Y, et al. Epidemiological and clinical characteristics of 99 cases of 2019 novel coronavirus pneumonia in Wuhan, China : a descriptive study. Lancet. 2020;395(10223):507-13.

113. Tu Y, Chien C, Yarmishyn AA, Lin Y, Luo Y-H, Lin Y-T, et al. A Review of SARS-CoV-2 and the Ongoing Clinical Trials. Int J Mol Sci. 2020;21(2657):1-19.

114. Kashiouris MG, L'Heureux M, Cable CA, Fisher BJ, Leichtle SW, Fowler III AA. The Emerging Role of Vitamin C as a Treatment for Sepsis. Nutrients. 2020;12(292):1-15.

115. Wang D, Hu B, Hu C, Zhu F, Liu X, Zhang J, et al. Clinical Characteristics of 138 Hospitalized Patients With 2019 Novel Coronavirus-Infected Pneumonia in Wuhan, China. JAMA - J Am Med Assoc. 2020;323(11):1061-1069.

116. Boretti $A$, Banik BK. Intravenous vitamin C for reduction of cytokines storm in acute respiratory distress syndrome. PharmaNutrition. 2020;12:1-8.

117. Zhou P, Yang X, Wang X, Hu B, Zhang L, Zhang W, et al. A pneumonia outbreak associated with a new coronavirus of probable bat origin. Nature. 2020;579(7798):270-3.

118. Yoshikawa T, Hill T, Li K, Peters CJ, Tseng CK. Severe Acute Respiratory Syndrome (SARS) CoronavirusInduced Lung Epithelial Cytokines Exacerbate SARS Pathogenesis by Modulating Intrinsic Functions of Monocyte-Derived Macrophages and Dendritic Cells. J Virol. 2009;83(7):3039-48.

119. Li Q, Guan X, Wu P, Wang X, Zhou L, Tong Y, et al. Early Transmission Dynamics in Wuhan, China, of Novel Coronavirus-Infected Pneumonia. N Engl J Med. 2020;382:1199-207.

120. Rabaan AA, Al-ahmed $\mathrm{SH}$, Haque $S$, Sah $R$, Tiwari $R, M a-$ lik YS, et al. SARS-CoV-2, SARS-CoV, and MERS-CoV: a comparative overview. Le Infez Med. 2020;(2):174-84.

121. Hui DS, Azhar El, Madani TA, Ntoumi F, Kock R, Dar O, et al. The continuing 2019-nCoV epidemic threat of novel coronaviruses to global health - The latest 2019 novel coronavirus outbreak in Wuhan, China. Int J Infect Dis. 2020;91:264-6.

122. Li G, De Clercq E. Therapeutic options for the 2019 novel coronavirus (2019-nCoV). Nat Rev Drug Discov. 2020;19(3):149-50.

123. Zhang W, Zhao Y, Zhang F, Wang Q, Li T, Liu Z, et al. The use of anti-inflammatory drugs in the treatment of people with severe coronavirus disease 2019 (COVID-19): 
The experience of clinical immunologists from China. Clin Immunol. 2020;214(108393).

124. Furuya A, Uozaki M, Yamasaki $H$, Arakawa $T$, Arita $M$, Koyama AH. Antiviral effects of ascorbic and dehydroascorbic acids in vitro. Int J Mol Med. 2008;22:541-5.

125. Campbell GJ, Steinberg M, Bower J. Ascorbic Acid-Induced Hemolysis in G-6-PD Deficiency. Ann Intern Med. 1975;82(6):810.

126. Rees DC, Kelsey H, Richards JDM. Acute haemolysis induced by high dose ascorbic acid in glucose6-phosphate dehydrogenase deficiency. Br Med J. 1993;306(6881):841-2.

127. Barton JC, McDonnell SM, Adams PC, Brissot P, Powell LW, Edwards CQ, et al. Management of hemochromatosis. Ann Intern Med. 1998;129(11):932-9.

128. Buehner M, Pamplin J, Studer L, Hughes RL, King BT, Graybill JC, et al. Oxalate nephropathy after continuous infusion of high-dose Vitamin $C$ as an adjunct to burn resuscitation. J Burn Care Res. 2016;37(4):e374-9.

129. Padayatty SJ, Sun AY, Chen Q, Espey MG, Drisko J, Levine M. Vitamin C: Intravenous use by complementary and alternative medicine practitioners and adverse effects. PLoS One. 2010;5(7).

130. Hemilä H. Vitamin C intake and susceptibility to pneumonia. Pediatr Infect Dis J. 1997;16(9):836-7.

131. Schorah CJ, Downing C, Piripitsi A, Gallivan L, Al-Hazaa $\mathrm{AH}$, Sanderson MJ, et al. Total vitamin C, ascorbic acid, and dehydroascorbic acid concentrations in plasma of critically ill patients. Am J Clin Nutr. 1996;63:760-5.

132. Hunt C, Chakravorty NK, Annan G, Habibzadeh N, Schorah CJ. The clinical effects of vitamin C supplementation in elderly hospitalised patients with acute respiratory infections. Int J Vitam Nutr Res. 1994;64:212-9.

133. Carr AC, Rosengrave PC, Bayer S, Chambers S, Mehrtens J, Shaw GM. Hypovitaminosis C and vitamin C deficiency in critically ill patients despite recommended enteral and parenteral intakes. Crit Care. 2017;21(300):1-10.

134. Arvinte $C$, Singh M, Marik PE. Serum Levels of Vitamin C and Vitamin D in a Cohort of Critically III COVID-19 Patients of a North American Community Hospital Intensive Care Unit in May 2020: A Pilot Study. Med Drug Discov. 2020;8:100064.

135. Marik PE. Vitamin C for the treatment of sepsis: The scientific rationale. Pharmacol Ther. 2018;189:63-70.

136. Khomich OA, Kochetkov SN, Bartosch B, Ivanov A V. Redox biology of respiratory viral infections. Viruses. 2018;10(392):1-27.

137. Padayatty SJ, Sun H, Wang Y, Riordan HD, Hewitt SM, Katz $A$, et al. Vitamin C Pharmacokinetics: Implications for Oral and Intravenous Use. Ann Intern Med. 2004;140:533-8.

138. Stephenson CM, Levin RD, Spector T, Lis CG. Phase i clinical trial to evaluate the safety, tolerability, and pharmacokinetics of high-dose intravenous ascorbic acid in patients with advanced cancer. Cancer Chemother Pharmacol. 2013;72:139-46.

139. Marik PE, Khangoora V, Rivera R, Hooper MH, Catravas J. Hydrocortisone, Vitamin C, and Thiamine for the Treatment of Severe Sepsis and Septic Shock: A Retrospective Before-After Study. Chest. 2017;151(6):1229-38.

140. Mousavi S, Bereswill S, Heimesaat MM. Immunomodulatory and antimicrobial effects of vitamin C. Eur J Microbiol Immunol. 2019;9(3):73-9.
141. Hartel C, Strunk T, Bucsky P, Schultz C. Effects of vitamin $\mathrm{C}$ on intracytoplasmic cytokine production in human whole blood monocytes and lymphocytes. Cytokine. 2004;27:101-6.

142. Maeng HG, Lim H, Jeong $Y$, Woo A, Kang JS, Lee WJ, et al. Vitamin $C$ enters mouse $T$ cells as dehydroascorbic acid in vitro and does not recapitulate in vivo vitamin $C$ effects. Immunobiology. 2009;214:311-20.

143. Parahuleva MS, Jung J, Burgazli M, Erdogan A, Parviz B, Hölschermann H. Vitamin $C$ suppresses lipopolysaccharide-induced procoagulant response of human monocyte-derived macrophages. Eur Rev Med Pharmacol Sci. 2016;20:2174-82.

144. Bowie AG, O'Neill LAJ. Vitamin C Inhibits NF-kB Activation by TNF Via the Activation of p38 Mitogen-Activated Protein Kinase. J Immunol. 2000;165:7180-8.

145. Fisher BJ, Seropian IM, Kraskauskas D, Thakkar JN, Voelkel NF, Fowler AA, et al. Ascorbic acid attenuates lipopolysaccharide-induced acute lung injury. Crit Care Med. 2011;39:1454-60.

146. Zhang M, Jativa DF. Vitamin $C$ supplementation in the critically ill: A systematic review and meta-analysis. SAGE Open Med. 2018;6:1-12.

147. Fowler AA, Truwit JD, Hite RD, Morris PE, Dewilde C, Priday $A$, et al. Effect of Vitamin C Infusion on Organ Failure and Biomarkers of Inflammation and Vascular Injury in Patients with Sepsis and Severe Acute Respiratory Failure: The CITRIS-ALI Randomized Clinical Trial. JAMA - J Am Med Assoc. 2019;322(13):1261-70.

148. Khoshnam-Rad N, Khalili H. Safety of Vitamin C in sepsis: A neglected topic. Curr Opin Crit Care. 2019;25(4): 329-33.

149. Holford P, Carr AC, Jovic TH, Ali SR, Whitaker IS, Marik PE, et al. Vitamin C-an Adjunctive Therapy for Respiratory Infection, Sepsis and COVID-19. 2020;12(12):3760.

150. Zhang J, Rao X, Li Y, Zhu Y, Liu F, Guo G, Luo G, Meng Z, De Backer $D$, Xiang $H$, Peng Z. Pilot trial of high-dose vitamin C in critically ill COVID-19 patients. Ann Intensive Care. 2021;11(1):5.

151. Chen Q, Espey MG, Sun AY, Lee JH, Krishna MC, Shacter $\mathrm{E}$, et al. Ascorbate in pharmacologic concentrations selectively generates ascorbate radical and hydrogen peroxide in extracellular fluid in vivo. Proc Natl Acad Sci U S A. 2007;104(21):8749-54.

152. Ma E, Chen P, Wilkins HM, Wang T, Swerdlow RH, Chen Q. Pharmacologic ascorbate induces neuroblastoma cell death by hydrogen peroxide mediated DNA damage and reduction in cancer cell glycolysis. Free Radic Biol Med. 2017;113:36-47.

153. Das UN. Vitamin C for Type 2 Diabetes Mellitus and Hypertension. Arch Med Res. 2019;50(2):11-4.

154. El-Aal AA, El-Ghffar EAA, Ghali AA, Zughbur MR, Sirdah $M M$. The effect of vitamin $C$ and/or E supplementations on type 2 diabetic adult males under metformin treatment: A single-blinded randomized controlled clinical trial. Diabetes Metab Syndr Clin Res Rev. 2018;12(483489).

155. Ellulu MS. Obesity, cardiovascular disease, and role of vitamin C on inflammation: a review of facts and underlying mechanisms. Inflammopharmacology. 2017;25(3):313-28.

156. Arshad MS, Khan U, Sadiq A, Khalid W, Hussain M, Yasmeen A, et al. Coronavirus disease (COVID-19) and immunity booster green foods: A mini review. Food Sci Nutr. 2020;8(8):3971-6. 
157. BourBour F, Mirzaei Dahka S, Gholamalizadeh M, Akbari $M E$, Shadnoush $M$, Haghighi $M$, et al. Nutrients in prevention, treatment, and management of viral infections; special focus on Coronavirus. Arch Physiol Biochem. 2020; 9:1-10.

158. Sies H, Parnham MJ. Potential therapeutic use of ebselen for COVID-19 and other respiratory viral infections. Free Radic Biol Med. 2020;156:107-12.

159. Horowitz RI, Freeman PR, Bruzzese J. Efficacy of glutathione therapy in relieving dyspnea associated with COVID-19 pneumonia: A report of 2 cases. Respir Med Case Reports. 2020;30:101063.

160. Spearow J, Copeland L. Review: Improving Therapeutics for COVID-19 with Glutathione-boosting Treatments that Improve Immune Responses and Reduce the Severity of Viral Infections. 2020; https://doi. org/10.31219/osf.io/y7wc2

161. Rogero MM, Leão $M$ de $C$, Santana TM, Pimentel MV de MB, Carlini GCG, Silveira TFF da, et al. Potential benefits and risks of omega-3 fatty acids supplementation to patients with COVID-19. Free Radic Biol Med. 2020;156:190-9.

162. Chen Q, Espey MG, Krishna MC, Mitchell JB, Corpe CP, Buettner GR, et al. Pharamacologic ascorbic acid concentrations selectively kill cancer cells: Action as a prodrug to deliver hydrogen peroxide to tissuse. Proc Natl Acad Sci U S A. 2005;102(38):13604-9.

163. Chen Q, Espey MG, Sun AY, Pooput C, Kirk KL, Krishna $M C$, et al. Pharmacologic doses of ascorbate act as a prooxidant and decrease growth of aggressive tumor xenografts in mice. Proc Natl Acad Sci U S A. 2008;105(32):11105-9.
164. Brown JM, Grosso MA, Terada LS, Beehler CJ, Toth KM, Whitman GJ, et al. Erythrocytes decrease myocardial hydrogen peroxide levels and reperfusion injury. Am J Physiol - Hear Circ Physiol. 1989;256(2):H584-8.

165. Chance $B$, Sies $H$, Boveris A. Hydroperoxide metabolism in mammalian organs. Physiol Rev. 1979;59(3):527-605.

166. Palsson-Mcdermott EM, O'Neill LAJ. The Warburg effect then and now: From cancer to inflammatory diseases. BioEssays. 2013;35(11):965-73.

167. Dang C V., Semenza GL. Oncogenic alterations of metabolism. Trends Biochem Sci. 1999;24(2):68-72.

168. Brand KA, Hermfisse U. Aerobic glycolysis by proliferating cells: a protective strategy against reactive oxygen species. FASEB J. 1997;11:388-95.

169. Schraufstatter IU, Hinshaw DB, Hyslop PA, Spragg RG, Cochrane CG. Oxidant injury of cells. DNA strand-breaks activate polyadenosine diphosphate-ribose polymerase and lead to depletion of nicotinamide adenine dinucleotide. J Clin Invest. 1986;77(4):1312-20.

170. Comelli M, Di Pancrazio F, Mavelli I. Apoptosis is induced by decline of mitochondrial ATP synthesis in erythroleukemia cells. Free Radic Biol Med. 2003;34(9):1190-9.

171. Schraufstatter IU, Hinshaw DB, Hyslop PA, Spragg RG, Cochrane CG. Glutathione cycle activity and pyridine nucleotide levels in oxidant-induced injury of cells. J Clin Invest. 1985;76:1131-9.

172. Erol A. High-dose intravenous vitamin $C$ treatment for COVID-19. 2020; https://doi.org/10.31219/osf.io/p7ex8

\section{Biohemija vitamina C: Od skorbuta do COVID-19 tretmana}

\author{
${ }^{1}$ Tamara Zakić, ${ }^{1}$ Marta Budnar, \\ ${ }^{1}$ Anđelika Kalezić, ${ }^{2}$ Aleksandra \\ Korać, 'Aleksandra Janković, \\ 1,2Bato Korać \\ ${ }^{1}$ Institut za biološka istraživanja „Siniša \\ Stanković"- Institut od nacionalnog \\ značaja za Republiku Srbiju, Univerzitet u \\ Beogradu, Bulevar despota Stefana 142, \\ Beograd 11060, Srbija; \\ ${ }^{2}$ Centar za elektronsku mikroskopiju, \\ Biološki fakultet, Univerzitet u Beogradu, \\ Studentski trg 16, Belgrade 11000, Srbija.
}

\begin{abstract}
Kratak sažetak
Priča o vitaminu C (L-askorbinska kiselina), antioksidansu i kofaktoru u brojnim biohemijskim reakcijama, deo je njegove duge istorije danas dobro poznata. Međutim, mnoga pitanja o mehanizmima njegovog delovanja i koristima koje on ostvaruje po ljudsko zdravlje se kontinuirano nameću. Ovo se odnosi ne samo na preporučene doze vitamina C, već i na način njegove primene. Pored toga, postoje brojna pitanja o efikasnosti vitamina $\mathrm{C} u$ terapiji različitih humanih infektivnih bolesti, njegovom antivirusnom potencijalu, kao i ulozi u funkcionisanju imunskog sistema. Činjenica da vitamin C može delovati kao redukciono sredstvo (antioksidant) i pro-oksidativno, dodatno naglašava njegov oksidaciono-redukcioni (redoks) potencijal u fiziološkim uslovima. Danas posebnu pažnja zahteva pitanje efekta intravenske primene vitamina C kod pacijenata sa SARS-CoV-2. Ovaj pregled ima za cilj da prikaže poznate činjenice o vitaminu Ci njegovim mehanizmima delovanja kako bi se bolje razumeli novi izazovi povezani sa vitaminom C.
\end{abstract}

Ključne reči: Vitamin C; Metabolizam; Antioksidant; Mehanizam delovanja; Fiziološka funkcija; Imuna funkcija; Kancer; Prehlada, SARS-CoV-2; COVID-19. 